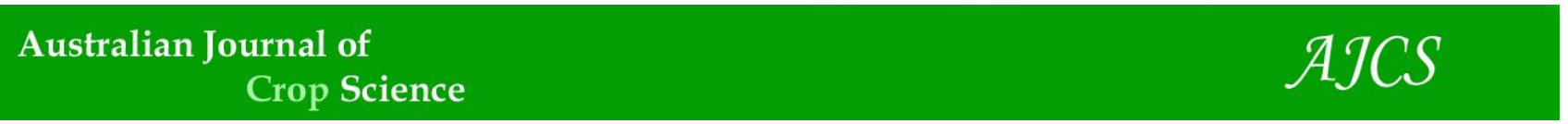

AJCS 14(08):1275-1282 (2020)

ISSN:1835-2707

doi: 10.21475/ajcs.20.14.08.p2433

\title{
Development and validation of chromatographic methods to quantify organic compounds in green coffee (Coffea arabica) beans
}

\author{
Wilder Douglas Santiago ${ }^{1}$, Alexandre Rezende Teixeira ${ }^{2}$, Juliana de Andrade Santiago ${ }^{1}$, Ana Cláudia \\ Alencar Lopes ${ }^{3}$, Rafaela Magalhães Brandão ${ }^{1}$, Alex Rodrigues Caetano ${ }^{1}$, Maria das Graças Cardoso ${ }^{1 *}$, \\ Mario Lúcio Vilela Resende ${ }^{2}$
}

\author{
${ }^{1}$ Chemistry Department, Federal University of Lavras, Lavras, MG, Brazil \\ ${ }^{2}$ Phytopathology Department, Federal University of Lavras, Lavras, MG, Brazil \\ ${ }^{3}$ Biology Department, Federal University of Lavras, Lavras, MG, Brazil
}

*Corresponding author: mcardoso@ufla.br

Abstract

Coffee is one of the oldest and most consumed beverages. The raw material for obtaining a good quality coffee drink is the grain. Bioactive compounds and organic acids in coffee beans are reflections of a series of attributes that, together, confer to the coffee peculiar flavor and aroma. This study aimed to identify trigonelline, chlorogenic acid, caffeine and organic acids in green coffee beans, and to validate the chromatographic method using High-Performance Liquid Chromatography (HPLC). Coffea arabica green coffee beans were used in this experiment. Trigonelline, chlorogenic acid, caffeine, and organic acids were identified and quantified by HPLC. Selectivity, linearity, limit of detection, limit of quantification, precision, and accuracy were used to validate the methods. Three bioactive compounds (trigonelline, chlorogenic acid, and caffeine) and seven organic acids (oxalic, citric, malic, quinic, succinic, lactic, and acetic acids) were quantified in the samples. The mean values for trigonelline, chlorogenic acid (5-ACQ), and caffeine ranged from 1.28 to $1.66,3.47$ to 4.73 and 1.26 to $1.59 \mathrm{~g} 100 \mathrm{~g}-1$, respectively. The values of organic acids, as well as the phenolic compounds, agree with those reported by the literature for green coffee beans of $C$. arabica. The validation parameters allowed the method to be considered linear, exact, and precise. Therefore, it resulted in a method reliable for studies of the composition of food matrix or quality control of green coffee beans.

Keywords: HPLC;Trigonelline, Chlorogenic acid, Caffeine, Organic acids.

Introduction

Coffee is mainly consumed by the infusion of Coffea arabica and Coffea canephora beans. The drink is known for its stimulating effect associated with caffeine and more recently it has been known other chemical constituents such as the chlorogenic acid with its antioxidant capacity, which has direct effects on human health (Alves et al., 2013; Durán et al., 2017)

Coffee is one of the main Brazilian commodities, being Arabica (Coffea Arabica L.) and robusta (Coffea canephora) varieties the most commercially important types (Dontg et al., 2017). The raw material to obtain a good quality coffee brew is the fully developed bean, mature and without damage of any order. The chemical compounds in coffee beans are reflections of a series of attributes that altogether confer the coffee a peculiar flavor and aroma (Malta et al., 2003; Rodarte et al., 2009).

The coffee chemical composition varies according to its species, which contributes to the fact that raw beans, when submitted to thermal treatments, provide beverages with different sensorial characteristics. It is also influenced by genetic variety, environmental conditions such as altitude, temperature and humidity, and post-harvest processing (Garret et al., 2013; Berthiot et al, 2012; Rendón et al, 2014; Durán et al, 2017). Among the bioactive compounds detected in coffee, the most important are trigonelline, caffeine, and organic acids (chlorogenic, citric, malic, quinic, oxalic, tartaric, malic, succinic, lactic, and acetic acids) (Kitzberger et al., 2013; Monteiroand Trugo, 2005).

High-performance liquid chromatographic (HPLC) has been the most used technique to determine these bioactive compounds in coffee beans (Dong et al., 2015; Fassio et al., 2016; Malta and Chagas, 2009; Maria and Moreira, 2005; Monteiro and Trugo, 2005; Rodarte et al., 2009). Despite the great use of this technique, there is little information in the literature about the standardization, optimization or validation of methods for the determination of these organic compounds in coffee beans.

Comparability, traceability, and reliability are being increasingly recognized and required to show the quality of chemical measurements. The unreliability of analytical data may lead to disastrous decisions and irreparable financial losses. To ensure that a new analytical method generates reliable and interpretable information about a sample, it needs to undergo an evaluation of standardization/optimization/validation. The validation of a method is an ongoing process that begins in the planning of the analytical strategy and continues throughout its 
development and transfer (Collins et al., 2007; Ribani et al., 2004).

Therefore, this study aimed to identify bioactive compounds (trigonelline, chlorogenic acid, and caffeine) and organic acids (oxalic, citric, tartaric, malic, quinic, succinic, lactic, and acetic acid) in Arabica green coffee beans, and validate the chromatographic method using high-performance liquid chromatography (HPLC) in their determination.

\section{Results and Discussion}

\section{Validation of methods}

The proposed methods allow the identification and quantification of organic compounds in green coffee beans. These compounds were identified by comparing their retention time (in minutes) to those standards and quantified using an external standard calibration. Figure 1 and 2 display the chromatographic profile of the studied organic compounds, where it is possible to observe their separation. The average retention time got for each analyzed bioactive compound was: Figure 1 (1) trigonelline (4.59 $\pm 0.15 \mathrm{~min}),(2)$ chlorogenic acid (10.94 $\pm 0.11 \mathrm{~min}$ ) and (3) caffeine (15.26 $\pm 0.19 \mathrm{~min})$. The retention time of acids were: Fig.2 (1) oxalic acid (12.30 $0.05 \mathrm{~min}),(2)$ citric acid (15.00 $\pm 0.1 \mathrm{~min}),(3)$ tartaric acid (15.85 $\pm 0.02 \mathrm{~min})$, (4) malic acid (17.04 $\pm 0.02 \mathrm{~min})$, (5) quinic acid (17.62 \pm 0.16 $\mathrm{min}),(6)$ succinic acid (19.54 $\pm 0.12 \mathrm{~min}),(7)$ lactic acid (20.19 $\pm 0.14 \mathrm{~min})$, and (8) acetic acid (22.26 $\pm 0.21 \mathrm{~min}$ ).

The selectivity, carried out by standard addition, was positive for the bioactive compounds since the curves showed a parallel slope for (1) trigonelline, (2) chlorogenic acid (5-CQA) and (3) caffeine (Figure 3, 4 and 5). Also, the selectivity of the organic acids was determined by the addition of standards to the green coffee bean matrix. According to the chromatogram, no interfering substances were observed in the sample at the retention time of the analytes (Figure 6). Thus, a positive selectivity may also be inferred for these organic acids.

The coefficients of determination, limits of detection and quantification, precision (coefficients of variation), and accuracy (recovery) obtained for the analytical methods are shown in Table 1.

The linearity was evaluated through the estimation of the coefficient of determination for the analytical curves obtained by linear regression. The coefficients of determination ranged from 0.9995 to 0.99998 (Table 1), which show the strong linear correlation between the compound concentration and peak area. All values were above 0.99, as recommended by the literature (Anvisa, 2003).

The limits of detection and quantification found for the bioactive compounds and organic acids are also displayed in Table 1. The obtained values for trigonelline, chlorogenic acid, and caffeine were higher than those values reported by Alves et al., (2006), Bispo et al., (2002), Rivelli et al., (2007) and close to those reported by Rodrigues et al. (2015). Even more, the values of the limits of detection and quantification of organic acids were similar to those found by Vignoli and Bassoli (2007). Rodrigues et al., (2007), when testing green coffee beans, observed that the limits of detection ranged from $0.4 \mathrm{mg} \mathrm{L-1for} \mathrm{the} \mathrm{malic} \mathrm{acid} \mathrm{to} 34 \mathrm{mg} \mathrm{L}-1$ for acetic acid; while the limits of quantification ranged from $1 \mathrm{mg} \mathrm{L-1}$ for the malic acid and $115 \mathrm{mg} \mathrm{L-1}$ for acetic acid, which are values close to those reported in this study. Since the limits of detection and quantification found in this study are close to other studies and the fact that they attend the determination of the compounds of interest in the sample, it can be inferred that the results were satisfactory. The accuracy of the method was evaluated through intermediary precision, estimating the coefficients of variation (CV) for each organic compound that were analyzed (Table 1). In both tests, CVs of the analyzed compounds were lower than the $5 \%$ limit (Anvisa., 2003; Collins et al., 2007; Harris., 2008). The results show that the present method can be applied to organic compounds in Arabica green coffee beans because, as in the literature, they presented a high degree of precision. Based on the acceptable limits of recovery (70-120\%), with an accuracy of $\pm 20 \%$, both methods showed good recovery. Indeed, the partial and mean values of recovery were all included within the acceptable limit range, ranging from 79 to $140 \%$ for trigonelline, chlorogenic acid, and caffeine, and 72-104\% for organic acids.

The acceptable recovery limit of more complex samples may be within 50 to $120 \%$. Studies with recovery values next to those found in this research have already been reported in the literature. Alves et al., (2006) presented recovery values of $95 \%$ for trigonelline, $103 \%$ for chlorogenic acid and $104 \%$ for caffeine. Also, Rivelli et al., (2007) quantified chlorogenic acid and caffeine in yerba mate tea and reported recovery values of $97 \%$ and $99 \%$, respectively. Vignoli and Bassoli (2007) found recovery values of $106.81,100.06$ and $104.76 \%$ for quinic, acetic and citric acid, which were values higher than those reported in this study. However, these authors could not show recovery values of malic and tartaric acid. Rodrigues et al., (2007) reported recovery values of 112, 95, 80,63 , and $93 \%$ for acetic, malic, quinic, and succinic acid, respectively.

All conditions and parameters used for the validation indicate that both methods showed linear, exact, and accurate results. However, some differences were observed when comparing these parameters with other authors' reports, which may be due to the different chromatographic conditions, such as apparatus and methodologies adopted for quantificationof the compounds (Ribani et al., 2004).

\section{Determination of trigonelline, chlorogenic acid (5-CQA) and caffeine in green coffee beans}

Quantification of trigonelline, chlorogenic acid (5-CQA) and caffeine in coffee has been widely used for discrimination of the coffee varieties. Also, these compounds have quality indicators because they confer functional properties to the beverage (Alves et al., 2006). Since these compounds act as stimulants and antioxidants, consumption of coffee brews with acceptable levels of chlorogenic acid, trigonelline and caffeine can bring health benefits (Lima et al., 2010). Trigonelline, chlorogenic acid (5-CQA) and caffeine analyzed in green coffee beans are displayed in Table 2.

The values obtained for trigonelline, chlorogenic acid (5CQA) and caffeine are in agreement with other values reported in the literature for green coffee beans of $C$. Arabica (Avelino et al., 2005; Bertrand et al., 2008; Duarte et al., 2010; Joet et al., 2010; Ky et al., 2001; Teixeira et al., 2012; Vignoli et al., 2014). Trigonelline ranged from 1.28 to

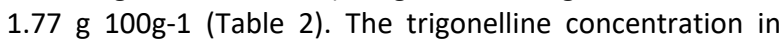
green coffee beans depends on the species and is strongly 
Table 1.Validation parameters of analytical methods of organic compounds.

\begin{tabular}{llllll}
\hline & $\mathrm{R}^{2}$ & $\begin{array}{l}\mathrm{LOD} \\
(\mathrm{mg} / \mathrm{mL})\end{array}$ & $\begin{array}{l}\mathrm{LOQ} \\
(\mathrm{mg} / \mathrm{mL})\end{array}$ & $\begin{array}{l}\text { Recovery } \\
(\%)\end{array}$ & $\begin{array}{l}\text { CV } \\
(\%)\end{array}$ \\
\hline Trigonelline & 0.99991 & 0.012 & 0.041 & $87-98$ & $0.423-0.995$ \\
Chlorogenic acid & 0.99996 & 0.008 & 0.027 & $79-102$ & $0.243-0.967$ \\
Cafeinne & 0.99998 & 0.009 & 0.032 & $91-104$ & $0.187-0.912$ \\
Oxalic acid & 0.9998 & 0.012 & 0.042 & $100-104$ & $0.406-1.091$ \\
Citric acid & 0.9997 & 0.022 & 0.073 & $72-77$ & $0.473-0.921$ \\
Tartaric acid & 0.9998 & 0.014 & 0.047 & $78-94$ & $0.254-1.362$ \\
Malic acid & 0.9995 & 0.008 & 0.027 & $77-84$ & $0.381-0.905$ \\
Quinic acid & 0.9996 & 0.014 & 0.046 & $75-83$ & $0.524-1.109$ \\
Succinic acid & 0.9994 & 0.021 & 0.071 & $75-86$ & $0.275-0.966$ \\
Lactic acid & 0.9998 & 0.011 & 0.032 & $74-81$ & $0.429-1.803$ \\
Acetic acid & 0.9999 & 0.019 & 0.064 & $78-86$ & $0.498-1.412$ \\
\hline * & & & & & \\
\hline
\end{tabular}

*Linear regression: $y=b x+a$; LOD: limit of detection; LOQ: limit of quantification; CV: coefficient of variation.

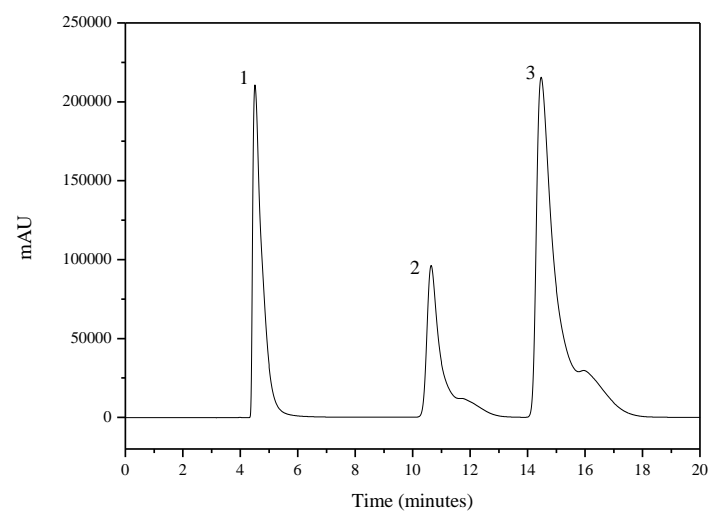

Fig 1. Chromatographic profile of the standard solution of (1) trigonelline, (2) chlorogenic acid (5-CQA) and (3) caffeine at $0,1 \mathrm{mg}$ $\mathrm{mL}^{-1}$.

Table 2. Mean values of trigonelline, chlorogenic acid, and caffeine (g/100g) in Arabica green coffee beans (Coffea arabica L.).

\begin{tabular}{llll}
\hline Sample & Trigonelline & $\begin{array}{c}\text { Chlorogenic acid } \\
(5-C Q A)\end{array}$ & Cafeinne \\
\hline 1 & $1.66 \mathrm{~b}$ & $4.73 \mathrm{~b}$ & $1.31 \mathrm{a}$ \\
2 & $1.39 \mathrm{~d}$ & $4.04 \mathrm{~b}$ & $1.26 \mathrm{a}$ \\
3 & $1.52 \mathrm{c}$ & $4.15 \mathrm{~b}$ & $1.35 \mathrm{a}$ \\
4 & $1.47 \mathrm{~d}$ & $4.46 \mathrm{~b}$ & $1.41 \mathrm{a}$ \\
5 & $1.43 \mathrm{~d}$ & $4.25 \mathrm{~b}$ & $1.35 \mathrm{a}$ \\
6 & $1.28 \mathrm{e}$ & $4.15 \mathrm{~b}$ & $1.34 \mathrm{a}$ \\
7 & $1.40 \mathrm{~d}$ & $3.95 \mathrm{~b}$ & $1.29 \mathrm{a}$ \\
8 & $1.42 \mathrm{~d}$ & $4.72 \mathrm{~b}$ & $1.38 \mathrm{a}$ \\
9 & $1.77 \mathrm{a}$ & $5.24 \mathrm{a}$ & $1.42 \mathrm{a}$ \\
10 & $1.535 \mathrm{c}$ & $4.66 \mathrm{~b}$ & $1.59 \mathrm{a}$ \\
11 & $1.555 \mathrm{c}$ & $3.47 \mathrm{c}$ & $1.48 \mathrm{a}$ \\
12 & $1.575 \mathrm{c}$ & $4.11 \mathrm{~b}$ & $1.31 \mathrm{a}$ \\
\hline
\end{tabular}

*Values followed by the same letter in the column do not differ from one another by the Scott-Knott test at $5 \%$ probability level. The standard deviation of all means presented low values, ranging from 0.001 to 0.070 .

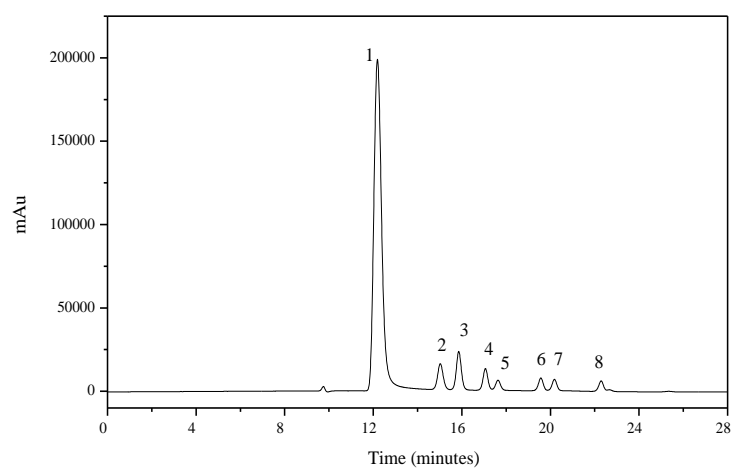

Fig 2. Chromatographic profile of the standard solution of (1) oxalic acid, (2) citric acid, (3) tartaric acid, (4) malic acid, (5) quinic acid, (6) succinic acid, (7) lactic acid and (8) acetic acid at $0,1 \mathrm{~g} \mathrm{~mL}^{-1}$. 
Table 3. Mean values of organic (g/100g) in Arabica green coffee beans (Coffea arabica L.).

\begin{tabular}{|c|c|c|c|c|c|c|c|c|}
\hline $\begin{array}{l}\text { Compounds/ } \\
\text { Samples }\end{array}$ & Oxalic acid & Citric acid & Tartarica cid & $\begin{array}{l}\text { Malic } \\
\text { acid }\end{array}$ & Quinic acid & Succinic acid & $\begin{array}{l}\text { Lactic } \\
\text { acid }\end{array}$ & $\begin{array}{l}\text { Acetic } \\
\text { acid }\end{array}$ \\
\hline 1 & $0.045 c$ & $1.011 \mathrm{~d}$ & ND & $0.308 c$ & $0.245 b$ & $0.235 c$ & $0.106 a$ & $1.263 \mathrm{~b}$ \\
\hline 2 & $0.063 b$ & $1.146 \mathrm{c}$ & ND & $0.389 \mathrm{~b}$ & $0.299 b$ & $0.258 c$ & $0.105 a$ & $0.947 d$ \\
\hline 3 & $<L Q$ & $1.307 a$ & ND & $0.442 a$ & $0.337 a$ & $0.289 b$ & $0.096 b$ & $1.037 c$ \\
\hline 4 & $0.056 b$ & $1.086 \mathrm{~d}$ & ND & $0.410 \mathrm{a}$ & $0.328 a$ & $0.372 \mathrm{a}$ & $0.078 b$ & $1.064 \mathrm{c}$ \\
\hline 5 & $0.061 b$ & $1.343 a$ & ND & $0.426 a$ & $0.337 a$ & $0.286 b$ & $0.119 a$ & $0.941 d$ \\
\hline 6 & $<\mathrm{LQ}$ & $1.033 d$ & ND & $0.388 b$ & $0.276 b$ & $0.219 c$ & $0.080 \mathrm{~b}$ & $0.947 d$ \\
\hline 7 & $0.069 b$ & $1.235 b$ & ND & $0.414 a$ & $0.308 a$ & $0.270 b$ & $0.108 a$ & ND* \\
\hline 8 & $0.060 \mathrm{~b}$ & $1.170 c$ & ND & $0.384 b$ & $0.279 b$ & $0.256 c$ & $0.115 a$ & $0.930 d$ \\
\hline 9 & $0.081 a$ & $1.310 \mathrm{a}$ & ND & $0.392 b$ & $0.302 a$ & $0.334 a$ & $0.104 a$ & $1.264 \mathrm{~b}$ \\
\hline 10 & $0.044 c$ & $1.148 c$ & ND & $0.430 a$ & $0.263 b$ & $0.301 b$ & $0.110 \mathrm{a}$ & $0.932 d$ \\
\hline 11 & $0.048 c$ & $1.278 b$ & ND & $0.409 a$ & $0.296 b$ & $0.261 \mathrm{c}$ & $0.096 b$ & $0.950 \mathrm{~d}$ \\
\hline 12 & $<\mathrm{LQ}$ & $0.748 \mathrm{e}$ & ND & $0.263 c$ & $0.192 c$ & $0.150 \mathrm{~d}$ & $0.053 c$ & $1.467 \mathrm{a}$ \\
\hline
\end{tabular}

**Values followed by the same letter in the column do not differ from one another by the Scott-Knott test at $5 \%$ probability level. The standard deviation of all means presented low values, ranging from 0.001 to 0.009

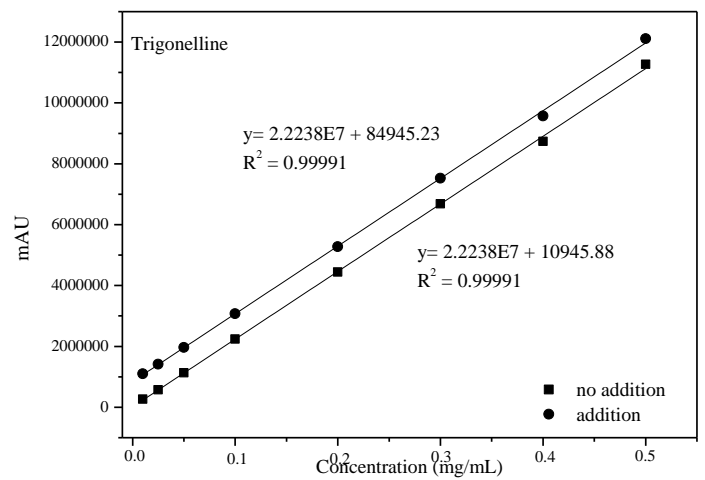

Fig 3. Linear equation with and without the addition of trigonelline (correlation coefficient $r^{2}$ ).

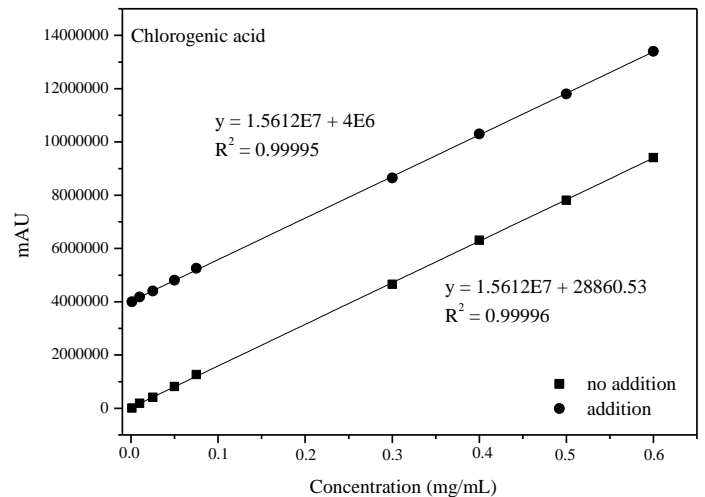

Fig 4. Linear equation with and without the addition of chlorogenic acid (correlation coefficient $r^{2}$ ).

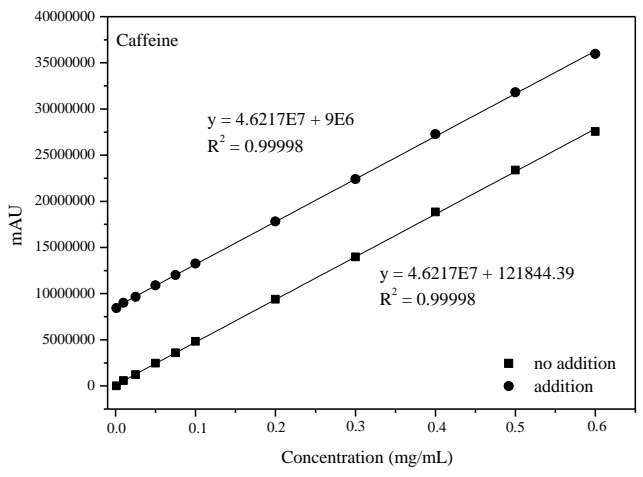

Fig 5. Linear equation with and without the addition of caffeine (correlation coefficient $r^{2}$ ). 


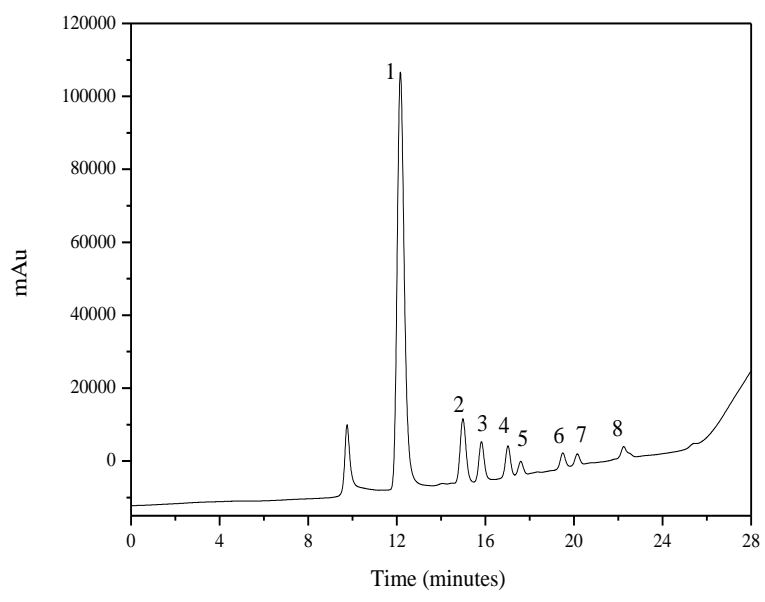

Fig 6. Chromatogram of a fortified sample in order to express the selectivity of the organic acids. (1) oxalic acid, (2) citric acid, (3) tartaric acid, (4) malic acid, (5) quinic acid, (6) succinic acid, (7) lactic acid and (8) acetic acid at $0.05 \mathrm{mg} \mathrm{mL}^{-1}$.

influenced by the genetic variety (Avelino et al., 2005; Leroy et al., 2006). 5-CQA is the most common chlorogenic acid isomer, which is found in considerable high concentrations in green coffee beans, and the most known biologically active dietary phenol (Chun et al., 2003). In this study, 5-CQA was detected in concentrations ranging from 3.60 to $5.59 \mathrm{~g}$ $100 \mathrm{~g}-1$. Unlike trigonelline and 5-CQA, caffeine is highly stable and does not undergo thermal degradation during the roasting process (Nogueira and Trugo, 2003). The caffeine content in Coffea arabica is usually between 0.8 and $2.8 \%$ (Heilmann, 2001). In this study, values from 0.95 to $2.19 \mathrm{~g}$ $100 \mathrm{~g}-1$ of caffeine were detected in the samples. Costa (2015) tested the content of bioactive compounds in green coffee beans of Acaiá (Coffea arabica) and detected 0.97, 1.15 and $2.09 \mathrm{~g} \mathrm{100g-1}$ of trigonelline, caffeine and chlorogenic acid, respectively, which are similar to the values found in this study. Also, studies on the trigonelline, 5-CQA, and caffeine present in Coffea Arabica beans submitted to different roasting degrees were, respectively, $1.5,1.0$ and $1.6 \mathrm{~g} 100 \mathrm{~g}-1$ in the light roasting, $0.3,0.7$ and $2.2 \mathrm{~g} 100 \mathrm{~g}$-1in the medium roasting, and $0.2,0.3$ and $1.9 \mathrm{~g}$ $100 \mathrm{~g}$-1in the dark roast (Morais et al., 2008). Based on the results reported by these authors, it is possible to observe a similarity with the results found in this work. Even more, trigonelline and 5-CQA in green coffee beans are higher than in roasted coffee beans, since these compounds may be degraded when submitted to the roasting process (Monteiro and Trugo, 2005). Marcucci et al., (2013) quantified trigonelline, 5-CQA and caffeine in Brazilian commercial soluble coffees. The authors detected values ranging from 0.47 to $2.15 \mathrm{~g} 100 \mathrm{~g}-1$ of trigonelline, 0.38 to $2.66 \mathrm{~g} 100 \mathrm{~g}-1$ of $5-\mathrm{CQA}$, and 2.32 to $4.08 \mathrm{~g} 100 \mathrm{~g}$-10f caffeine. Comparing these results with those reported here, it can be inferred that the manufacturing of soluble coffee also causes a loss in the levels of trigonelline and 5-CQA.

\section{Determination of organic acids in green coffee beans}

The results of the analyzed organic acids are presented in Table 3

According to the date shown in Table 3, tartaric acid was not detected in any sample. These results are consistent with analyses of organic acids in green coffee beans, since the main detected organic acids are citric, malic and quinic acid (Balzer, 2001). Citric, oxalic, malic, quinic, succinic, lactic and acetic acid fluctuated from 0.7485 to $1.3432,0.0445$ to $0.0815,0.2638$ to $0.4425,0.1927$ to $0.3376,0.1505$ to

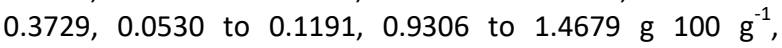
respectively (Table 3 ). Oxalic acid was not detected in samples 3, 6 and 12, and acetic acid was not identified in sample 7. Monteiro and Trugo (2005) reported that the total chlorogenic and quinic acid in green coffee beans were approximately 6.0 and $0.4 \mathrm{~g} 100 \mathrm{~g} 1$. Muller and Hofmann (2005) evaluated organic acids in Arabica green coffee beans of Colombia and detected concentrations of citric, malic, quinic, acetic, and lactic acid of 1.7, 0.82, 0.5, 0.148 and 0.24 g $100 \mathrm{~g}^{-1}$, respectively. These reported values are close to those results found by using the proposed method in this study.

\section{Materials and Methods}

This study was performed at the laboratory of National Institute of Coffee Science and Technology (INCT-CAFÉ) at the Federal University of Lavras in the period from February to April 2019. The university is located in the city of Lavras in the state of Minas Gerais at an altitude of $919 \mathrm{~m}$ and geographical coordinates: Latitude 210 14 '43 " South and Longitude 44은 59" West.

\section{Sampling}

Green coffee beans (Coffea arabica L.) of the 2016/17 crop were produced in the western center of Minas Gerais Brazil, in the cities of Piumhi, Bambui, Doresópolis, Pimenta and São Roque de Minas. The coffee bags were stored in closed sheds at controlled temperature $\left(23-28{ }^{\circ} \mathrm{C}\right)$ and humidity ( $65-76 \%$ ). Samples were randomly selected from the bags to obtain the extracts and numbered from 1 to 12 . Green coffee beans were milled in an analytical mill (IKA, model A11Basic) with the addition of liquid nitrogen for approximately one minute, which was then passed through a 200 mesh sieve. 


\section{Extraction and determination of trigonelline, chlorogenic acid (5-CQA) and caffeine}

The bioactive compounds were extracted using $0.5 \mathrm{~g}$ of milled coffee beans in $50 \mathrm{~mL}$ of boiling distilled water or 3 $\mathrm{min}$ in a water bath. The extracts were filtered on filter aper, polyethylene membrane $(0,45 \mu \mathrm{m}$; Millipore), and submitted to chromatographic analyzes (Malta and Chagas, 2009).

Trigonelline, chlorogenic acid (5-CQA) and caffeine were quantified according to the method proposed by Malta and Chagas (2009) with minor modifications. The chromatographic analysis was performed in a liquid chromatography system (Shimadzu HPLC), equipped with a high-pressure quaternary pump model LC-20AT, degasser model DGU-20A5, interface model CBM-20A, an automatic injector model SIL-20A-HT, and UV-Vis detector (SPD-20A). Separations were carried out in a Supelcosil LC-C18 column $(4,6 \times 250 \mathrm{~mm}, 5 \mu \mathrm{m})$ connected to a Supelcosil C18 precolumn $(4,6 \times 12,5 \mathrm{~mm}, 5 \mu \mathrm{m})$. Elution was achieved with an isocratic system of $1 \%$ glacial acetic acid in type I water (Solvent A), methanol:water:acetic acid (85:14:1\% v/v)

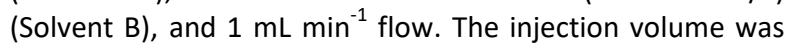
$20 \mu \mathrm{L}$ and a wavelength of $272 \mathrm{~nm}$. All used solvents were of analytical grade for HPLC: methanol (Merck), glacial acetic acid (J. T. Baker) and type I water obtained from a Milli-Q system. Quantification was done by external calibration. A stock solution of all standards $(1 \mathrm{mg} / \mathrm{mL})$ (Sigma-Aldrich ${ }^{\circledR}$ ) was prepared in type I water, from which several dilutions, ranging from 0.01 to $0.7 \mathrm{mg} / \mathrm{mL}$, were prepared to construct the analytical curve. All samples and standards solutions were analyzed in triplicate.

\section{Extraction and determination of organic acids}

The organic acids were extracted by diluting $0.5 \mathrm{~g}$ of the milled sample into $50 \mathrm{~mL}$ of $0.23 \%$ perchloric acid (SigmaAldrich $\left.^{\circledast}\right)$. The mixture was transferred to a $50 \mathrm{~mL}$ Falcon tube and vortexed for $3 \mathrm{~min}$ (Ribeiro et al., 2018).

Quantification was carried out by the method of Jham et al., (2002) with some modifications. The extracts were filtered on a quantitative filter paper of polyethylene $(0.45 \mu \mathrm{m}$; Millipore) and $20 \mu \mathrm{L}$ were directly injected in the chromatographic system. The equipment was the same one mentioned in the previous analyses, but with a wavelength of $210 \mathrm{~nm}$. Separation was conducted in a Supelcogel-C610H (300 mm x 7,8 mm d.i.) column and a Supelguard $\mathrm{C} 610 \mathrm{H}$ $(5 \mathrm{~cm} \times 4,6 \mathrm{~mm}$ d.i) pre-column. Elution was performed with a gradient system of $0.23 \%$ perchloric acid aqueous solution (Sigma-Aldrich ${ }^{\circledast}$ ) according to the flow velocity gradient from 0 to $13 \mathrm{~min}(0.5-0.3 \mathrm{~mL} / \mathrm{min}) ; 13-16 \mathrm{~min}(0.3-0.5 \mathrm{~mL} / \mathrm{min})$; $16-24 \mathrm{~min}(0.5-0.8 \mathrm{~mL} / \mathrm{min}) ; 24-28 \mathrm{~min}(0.8-0.5 \mathrm{~mL} / \mathrm{min})$.

Oxalic, citric, tartaric, malic, quinic, succinic, lactic, and acetic acid were quantified by external calibration. A stock solution of all standards $\left(1 \mathrm{mg} / \mathrm{mL}\right.$ ) (Sigma-Aldrich ${ }^{\circledR}$ ) was prepared in type I water, from which different dilutions ranging from 0.00025 to $1 \mathrm{mg} / \mathrm{mL}$ were prepared to build the analytical curve. All samples and standard solutions were analyzed in triplicate.

\section{Validation parameters}

The parameters used to validate the chromatographic methods and ensure the good analytical quality of the results were selectivity, linearity, limits of detection, limits of quantification, precision and accuracy (Anvisa, 2003; Harris, 2008; Ribani et al., 2004).

The selectivity was assessed by comparing the analytical curve of the sample with the addition of the standards to the analytical curve of the sample without the substances of interest. This procedure was performed to trigonelline, chlorogenic acid, and caffeine. For the organic acids, the standards were added at a concentration of $0.05 \mathrm{mg} / \mathrm{mL}$ to a matrix of coffee. Linearity was obtained by external standardization, testing the correlation of the signal (peak area) with the concentration of the compound of interest, which was expressed by the analytical curve equation and its respective determination coefficient $\left(R^{2}\right)$. The limit of detection (LOD) and limit of quantification (LOQ) were determined from the parameters of the analytical curve. Both were calculated using the mathematical correlations: $L O D=3 s / s$ and $L O Q=10 s / S$, where $s$ is the estimated standard deviation of the regression line and $\mathrm{S}$ is the angular coefficient of the analytical curve. Precision was assessed by intermediate precision method and analyses of 3 concentrations $(0.01 ; 0.1$ and $0.7 \mathrm{mg} / \mathrm{mL})$ of standard solutions performed in 5 different days. The values were estimated according to the coefficient of variation (CV) of a series of measures by the mathematical correlation CV (\%) = $s / C D M$, where $s$ is the standard deviation and CDM is the mean concentration. Accuracy was assessed by recovery assays using three randomly selected samples, to which the analyte standard was added at three different concentrations $(0.01,0.1$ and $0.7 \mathrm{mg} / \mathrm{mL})$. Recovery was determined considering the obtained results for the analyte using the following mathematical correlation: Recovery $(\%)=$ [(observed concentration)/(expected concentration] x 100 (Anvisa, 2003; Harris, 2008; Ribani et al., 2004).

\section{Statistical analysis}

All experiments were carried out in a completely casual experimental design with analyses in triplicate. The data were submitted to an analysis of variance, and means were compared by the Scott-Knott test at $5 \%$ probability level using the SISVAR statistical program (Ferreira, 2011).

\section{Conclusions}

The chromatographic methods used in this study determined and quantified trigonelline, chlorogenic acid, caffeine, and organic acids (oxalic, citric, malic, quinic, succinic, lactic, and acetic acid) in Arabica green coffee beans. These compounds are considered of great importance and indicate the quality of the coffee. Both chromatographic methods were linear, exact, and accurate, which means that the bioactive compounds and organic acids can be identified and quantified with safety and reliability.

\section{Acknowledgements}

This work was supported by Fundação de Amparo à Pesquisa de Minas Gerais (FAPEMIG), the Conselho Nacional de Desenvolvimento Científico e Tecnológico (CNPq), the Instituto Nacional de Ciência e Tecnologia do Café (INCT(AFÉ) and the Higher Education Personel Improvemente Coordenation (CAPES) - Finance code 001. The authors thank the scholarships and financial support. 
Agência Nacional de Vigilância Sanitária (ANVISA) (2003) Guia para a avaliação de métodos analíticos e bioanalíticos. 1-12.

Alves RC, Casal S, Oliveira B, (2009) Beneficios do café na saúde: Mito ou Realidade? Quim Nova. 32:2169-2180.

Alves ST, Dias RC E, Benassi MDT, Scholz MDS (2006) Metodologia para análise simultânea de ácido nicotínico, trigonelina, ácido clorogênico e cafeína em café torrado por cromatografia líquida de alta eficiência. Quim Nova. 29:1164-1168.

Avelino J, Barboza B, Araya JC, Fonseca C, Davrieux F, Guyot B, Cilas C (2005) Effects of slope exposure, altitude and yield on coffee quality in two altitude terroirs of Costa Rica, Orosi and Santa María de Dota. J Sci Food Agric. 85:1869-1876.

Balzer HH (2001) Acids in coffee. Coffee: recent developments. Hoboken, N J USA: Blackwell Science Ltd.

Berthiot L, Descroix F, Joet T (2012) Climatic factors directly impact the volatile organic compound fingerprint in green Arabica coffee bean as well as coffee beverage quality. Food Chem. 135:2575-2583.

Bertrand B, Villarreal D, Laffargue A, Posada H, Lashermes P, Dussert $S$ (2008) Comparison of the effectiveness of fatty acids, chlorogenic acids, and elements for the chemometric discrimination of coffee (Coffea arabica L.) varieties and growing origins. J Agric Food Chem. 56:22732280.

Bispo MS, Veloso MCC, Pinheiro HLC, De Oliveira RF, ReisJON, De Andrade JB (2002) Simultaneous determination of caffeine, theobromine, and theophylline by high-performance liquid chromatography. J Chromatogr Sci. 40:45-48.

Chun OK, Kim DO, Moon HY, Kang HG, Lee CY (2003) Contribution of individual polyphenolics to total antioxidant capacity of plums. J Agric Food Chem. 51:72407245.

Collins CH, Braga GL, Bonato PS (2007) Fundamentos de cromatografia. Campinas, SP, Brazil: ed Unicamp.

Costa MC (2015) Compostos bioativos e atividade sequestrante de radicais livres de quatro cultivares do Coffea arabica L. em diferentes estádios de maturação dos frutos. PhD Thesis, Universidade Estadual Paulista, The Brazil.

Dong W, Hu R, Chu Z, Zhao J, Tan L (2017) Effect of different drying techniques on bioactive components, fatty acid composition, an volatile profile of robusta coffee beans. Food Chem. 234:121-130.

Dong W, Tan L, Zhao J, Hu R, Lu M (2015) Characterization of fatty acid, amino acid and volatile compound compositions and bioactive components of seven coffee (Coffea robusta) cultivars grown in Hainan Province, China. Molecules. 20:16687-16708.

Duarte GS, Pereira AA, Farah A (2010) Chlorogenic acids and otherrelevantcompounds in Brazilian coffees processed by semi-dry and wet post-harvesting methods. Food Chem. 118:851-855.

Durán CAA, Tsukui A, Santos FKF, Martinez ST, Bizzo HR, Rezende CM (2017) Café: Aspectos gerais e seu aproveitamento para além da bebida. Rev Virt Química. 9:107-134.

Fassio LO, Malta M, Carvalho G, Liska G, de Lima P, Pimenta C (2016) Sensory description of cultivars (Coffea arabica L.) resistant to rust and its correlation with caffeine, trigonelline, and chlorogenic acid compounds. Beverages. 2:1-12.

Ferreira D F (2011) SISVAR: a computer statistical analysis system. Cienc Agrotecnol. 35:1039-1042.

Garret R, Schimidt EM, Pereira LFP, Kitzberger, CSG, Scholz, MBA, Erbelin MN, Rezende CM (2013) Discrimination of Arabica Coffee cultivars by electrospray ionization Fourier transform ion cyclotron resonance mass spectrometry and chemometrics. LWT Food Sci Technol. 50:496-502.

Harris DC (2008) Análise química quantitativa. Rio de Janeiro, Brasil: LTC.

Heilmann W (2001) Tecnology II: decaffeination of coffee. In: Clark, R. J.; Vitztum, O.G. (Eds.). Coffee: recent development. Oxford: Blackwell Science (108-124).

Jham GN, Fernandes SA, Garcia CF, Silva AA (2002) Comparison of GC and HPLC for the quantification of Organic Acids in Coffee. Phytochem Anal. 13:99-104.

Joët T, Laffargue A, Descroix F, Doulbeau S, Bertrand B, Dussert $S$ (2010) Influence of environmental factors, wet processing and their interactions on the biochemical composition of green Arabica coffee beans. Food chem. 118:693-701.

Kitzberger CSG, dos Santos SMB, Pereira LFP, Benassi MT (2014) Composição química de cafés árabica de cultivares tradicionais e modernas. Pesqui Agropecu Bras. 48:14981506

Ky CL, Louarn J, DussertS, Guyot B, Hamon S, Noirot M (2001) Caffeine, trigonelline, chlorogenic acids and sucrose diversity in wild Coffea arabica L. and C. canephora P. accessions. Food chem. 75:223-230.

Leroy $T$, Ribeyre $F$, Bertrand $B$, Charmetant $P$, Dufour $M$, Montagnon C, Marraccini P, Pot D (2006) Genetics of coffee quality. Braz J Plant Physiol. 18:229-242.

Lima AR, Pereira RGFA, AbrahãoSA, Duarte SMDS, Paula FBDA(2010) Coffee bioactive compounds: in vitro antioxidant activity of green and roasted coffees before and after decaffeination. Quim Nova. 33:20-24.

Malta MR, Nogueira FD, Guimarães PTG (2003) Composição química, produção e qualidade do café fertilizado com diferentes fontes e doses de nitrogênio. Cienc Agrotecnol. 27:1246-1252.

Malta MR, Chagas SJR (2009) Avaliação de compostos nãovoláteis em diferentes cultivares de cafeeiro produzidas na região Sul de Minas Gerais. Acta Sci Agron. 31:57-61.

Marcucci CT, Benassi MT, Almeida MB, Nixdorf SL (2013) Teores de trigonelina, ácido 5-cafeoilquínico, cafeína e melanoidinas em cafés solúveis comerciais brasileiros. Quim Nova. 36:544-548.

Maria CAB, Moreira RFA (2007) Cafeína: revisão sobre métodos de análise. Quim Nova. 30: 99-105.

Monteiro MC, Trugo LC (2005) Determinação de compostos ativos em amostras comerciais de café torrado. Quim Nova. 28:637-641.

Morais SAL, Aquino FJT, Nascimento EA, Oliveira GS, Chang R, Santos NC, Rosa GM (2008) Análise de compostos bioativos, grupos ácidos e da atividade antioxidante do café arábica (Coffea arábica) do cerrado e de seus grãos defeituosos (PVA) submetidos a diferentes torras. Cienc Tecnol Aliment. 28:198-207.

Müller C, Hofmann T (2005) Screening of raw coffee for thiol binding site precursors using "in bean" model roasting experiments. J Agric Food Chem.53:2623-2629. 
Nogueira M, Trugo LC (2003) Distribuição de isômeros de ácido clorogênico e teores de cafeína e trigonelina em cafés solúveis brasileiros. Cienc Tecnol Aliment. 23:296299.

Rendón MY, Silva TJG, Bragagnalo N (2014) Impact of chemical change on the sensory characteristics of beans during storage. Food Chemistry. 147:279-286.

Ribani M, Bottoli CBG, Collins CH, Jardim ICSF, Melo LFC (2004) Validação em métodos cromatográficos e eletroforéticos. Quim Nova. 27:771-780.

Ribeiro ER, Borém FM, Nunes CA, Alves APC, Santos CM, Taveira JHS, Dias LLC (2018) Profile of Organic Acids and Bioactive compounds in the sensory quality discrimantion of Arabic Coffee. Coffee Science.13:192-202.

Rivelli DP, Silva VVD, Ropke CD, Miranda DV, Almeida RL, Sawada TCH, Barros SBDM (2007) Simultaneous determination of chlorogenic acid, caffeic acid and caffeine in hydroalcoholic and aqueous extracts of llex paraguariensis by HPLC and correlation with antioxidant capacity of the extracts by DPPH - reduction. Rev Bras Cienc Farm. 43:215-222.
Rodarte MP, AbrahãoSA, Pereira RGFA, Malta MR (2009) Compostos não voláteis em cafés da região sul de Minas submetidos a diferentes pontos de torração. Cienc Agrotecnol. 33:1366-1371.

Rodrigues $\mathrm{Cl}$, MartaL, MaiaR, Miranda $\mathrm{M}$, Ribeirinho $\mathrm{M}$, Máguas C (2007) Application of solid-phase extraction to brewed coffee caffeine and organic acid determination by UV/HPLC. J Food Compos Anal. 20:440-448.

Rodrigues NP, Salva TJG, Bragagnolo N (2015) Influence of Coffee Genotype on Bioactive Compounds and the in Vitro Capacity To Scavenge Reactive Oxygen and Nitrogen Species. J Agric Food Chem. 63:4815-4826.

Teixeira AL, Prado PER, das Graças DKO, Malta MR, Gonçalves FMA (2012) Avaliação do teor de cafeína em folhas e grãos de acessos de café arábica. Rev Cienc Agron. 43:129-137.

Vignoli JA, Bassoli DG (2007) Determinação de ácidos carboxílicos e fenólicos em café solúvel utilizando HPLC/DAD. Revista Analytica. 27:76-79.

Vignoli JA, Viegas MC, Bassoli DG, Toledo BM (2014) Roasting process affects differently the bioactive compounds and the antioxidant activity of arabica and robusta coffees. Food Res Int. 61:279-285. 